\title{
Effects of Some Antioxidant Materials as a Foliar and Water Deficit Stress at Identify Growth Stages on Productivity of Wheat Crop Mohamed, A. A. A. and E. A. Abo-Marzoka \\ ${ }^{1}$ Agronomy Dept., Fac. of Agric., Kafrelsheikh Univ., Egypt. \\ ${ }^{2}$ Crop Physiology Research Department, Field Crop Res. Inst., ARC, Giza, Egypt.
}

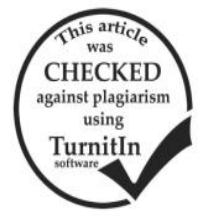

\section{ABSTRACT}

Two field experiments were conduct at Sakha Agric. Res. Station,Kafer EL-Sheikh Governorate, Egypt during 2013/2014 and 2014/2015 seasons, to study the effects of foliar application of ascorbic and salicylic acid under water deficit stressat identify growth stages and its interaction on productivity of misr1 wheat cultivar. The split plot design with three replicates was used where the main plots included water stress (normal irrigation, water deficit stress attillering, heading, ripening stages), while ascorbic and salicylic acid applications (water spray, Asc 100 ppm, Asc 200 ppm, sal 100 ppm, sal 200 ppm, Asc 100 ppm + sal $100 \mathrm{ppm}$, Asc $200 \mathrm{ppm}+$ sal $100 \mathrm{ppm}$, Asc $200 \mathrm{ppm}+$ sal $200 \mathrm{ppm}$ ) were allocated at the sub plots. The obtained results were as follows:The normal irrigation recorded the highest signicficantly values in chlorophyll a, chlorophyll $b$, flage leaf area, plant height, spike length, number of spikes $/ \mathrm{m}^{2}$, number of grains/spike, grains weight/spike, 1000 grain weight, grain yeild/fed. and straw yeild/fed. characters without significantly differences with the treatment of water deficit stress at heading and ripening stages at chlorophyll ain both seasons, the normal irrigation did not significantly differed with the treatments of water deficit stress at tillering, heading and ripening stages in grains weight/spike, grain yeild and plant heighet characters respictively in the first season and with the treatments of water deficit stress atheading stage in number of grains/spike and spike length characters and at ripening stage in spike length character in the second season. The combinations between ascorbic acid and salicylic acid gave the greatest significantly values at the most of characters as soon as chlorophyll a, plant height, spike length, number of spikes $/ \mathrm{m}^{2}$, number of grains/spike, grains weight/spike, grain yeild/fed. and straw yeild/fed. characters compared with the other treatments in both seasons while the same trend was at chlorophyll $\mathrm{b}$ in the first season and at 1000 grain weight in the second season, the combination between ascorbic acid $(200 \mathrm{ppm})$ and salicylic acid $(200 \mathrm{ppm})$ only recorded the greatest significantly values offlage leaf area in both seasons and at 1000 grain weight andchlorophyll $\mathrm{b}$ in the first and second season respectivly, the combinations between ascorbic acid and salicylic acid under normal irrigation gave the highest significantly values of grain yield/fed. in both seasons without significantly differences with the same combinations under water deficit stress at heading stage in the first seasons. The normal irrigation received the greatest values of water applied $\left(\mathrm{m}^{3} / \mathrm{fed}\right)$ and water consumption $\left(\mathrm{m}^{3} / \mathrm{fed}\right)$ while treatments of water deficit stress at heading and ripening stages recorded the highest values of productivity of irrigation water $\left(\mathrm{kg} / \mathrm{m}^{3}\right)$ and water productivity index $\left(\mathrm{kg} / \mathrm{m}^{3}\right)$, the combinations between ascorbic acid and salicylic acid recorded the biggest values of water applied $\left(\mathrm{m}^{3} / \mathrm{fed}\right)$, water consumption $\left(\mathrm{m}^{3} / \mathrm{fed}\right)$, productivity of irrigation water $\left(\mathrm{kg} / \mathrm{m}^{3}\right)$ and water productivity index $\left(\mathrm{kg} / \mathrm{m}^{3}\right)$ characters compared with the other antioxidant treatments in both seasons. The combinations between ascorbic acid (200 ppm) and $100 \mathrm{ppm}$ or $200 \mathrm{ppm}$ salicylic acid at all water deficit stress treatments recorded the highest values of productivity of irrigation water $\left(\mathrm{kg} / \mathrm{m}^{3}\right)$ and water productivity index $\left(\mathrm{kg} / \mathrm{m}^{3}\right)$ compared with the other interactions, the lowest values of the previous characters were obtained from water spray at all water deficit stress treatments. It could be concluded that the combinations between ascorbic acid $(200 \mathrm{ppm})$ and $(100 \mathrm{ppm}$ or $200 \mathrm{ppm})$ of salicylic acid as a foliar application under both normal irrigation and water deficit stress at heading stage producing the highest grain yield of Misr 1 wheat cultivar with increasing the productivity of irrigation water and water productivity index Under the conditions of this study.

Keywords: ascorbic acid, salicylic acid, water deficit stresses, Misr 1wheat cultivar, yield.

\section{INTRODUCTION}

Wheat crop owing a central role in world's food security.It is the principal food formore than one-fifth of human populace in the world. It is considered one of the most important strategically crop especially in Egypt (FAO, 2014). The national target in Egypt is increasing wheat productivity to fill the gap between the local consumption and production. The different abiotic stresses lead to decrease wheat productivity so, it is important to minimize these losses to face the increase in food requirements (Maswada and Abd El-Kader, 2016).

Response to water deficit stress related to the other factors such as duration, the intensity of stress, the developmental stage or growth of the plants. Plant growth reduces by water deficit stress through affecting various physiological processes, such as photosynthesis, translocation, nutrient metabolism and growth promoters (Azadeh et al., 2014; Abdalla, 2011 and Amin, et al., 2009).Water deficit stress led to the plant will face the oxidative damage inevitably and can be resulted in producing reactive oxygen species (ROS), which are the result of incomplete reduction of oxygen and toxic for plant cells (Miyake, 2010), the reduction in fresh and dry biomass production resulted from water deficit stress on crop plants (Lisar et al., 2012).

The antioxidant materials as soon as ascorbic acid and salicylic acid play an important role in the defense against oxidative stress. The recent results, using the transgenic plantsand mutants, confirmed the role of ascorbic acid in photosynthesis, the cycle of ascorbic acid in oxidative stress, but the amount of ascorbic acid was also increased in the plants under stress. The results of the studies of Malik et al (2015)showed that application of ascorbic acid under drought to overcome adverse effects of oxidative stress by maintaining growth, relative water content, osmotic adjustment through proline accumulation and by enhanced activity of antioxidant enzymes, Noreen et al.(2008) and Amirkhan et al.(2006) showed that ascorbic acid at the rate of (100 ppm) in wheat caused the reduction of adverse effects of drought stress. Farjam et al. (2015) showed that ascorbic acid application increased rate of biological WUE significantly as compared with control plants, application of salicylic acid led to significant increase in leaves protein content in complete drought stress condition, application of ascorbic acid at non-stress (control) condition resulted in the highest economical rate of WUE. 
Salicylic acid was the organic compound in the plants, it affects the physiological activities in the plants, such as growth regulation, photosynthesis, nutrient uptake, plant water relations and mechanisms of plant resistance and tolerance to biotic and abiotic stresses (Hayat et al. 2010; Popova et al. 1997). Application of SA stimulated tolerance in plantsto many biotic and abiotic stress(Khan et al., 2010). Amin et al. (2008) reported that foliar application of wheat plants (Triticumaestivum L.) CV. Gemmiza 10 with the combinations between salicylic acid at rate of $100 \mathrm{mg} \mathrm{l} 1-1$ and ascorbic acid at rate of 200 or 400 mg 1-1were more effective in increasing growth characters, yield and its components in addition to chlorophyll content in the leaves compared with untreated plants., Shirazi et al. (2014) studied the effect of four irrigation regimes ((no irrigation), $100 \mathrm{~mm}$ at 30 days after sowing (DAS), $200 \mathrm{~mm}(100 \mathrm{~mm}$ at $30 \mathrm{DAS}+100 \mathrm{~mm}$ at $45 \mathrm{DAS})$, and $300 \mathrm{~mm}(100 \mathrm{~mm}$ at 30 DAS $+100 \mathrm{~mm}$ at 45 DAS + $100 \mathrm{~mm}$ at 60 DAS)). They reported that the maximum grain yield was obtained from application of $200 \mathrm{~mm}$ $(100 \mathrm{~mm}$ at $30 \mathrm{DAS}+100 \mathrm{~mm}$ at $45 \mathrm{DAS})$ irrigation treatment. Bakry et al. (2013).They found that highest grain yield resulted from water $80 \%$ of irrigation requirement without significantly differences with the treatment of $100 \%$ water irrigation. The greatest values of grain and straw yields/fad, protein content, plant height, spike length, seed index, number of spikelet's per spike and water use efficiency produced from Increasing foliar application levels of ascorbic acid.The interaction between $80 \%$ water irrigation requirements and $300 \mathrm{mg} / \mathrm{L}$ level of ascorbic acid as foliar application gave the highest values of grain, straw, protein yields /fad. and water use efficiency.

The aim of this investigation was study the effect of foliar application of ascorbic and salicylic acid under water deficit stress at identifies growth stages and its interaction on productivity of Misr1 wheat cultivar.

\section{MATERIALS AND METHODS}

Two field experiments were conduct at the Experimental Farm of Sakha Agricultural Research Station, at Kafr El-Sheikh Governorate, Agricultural Research Center, (ARC), Egypt during the two growing seasons, 2013/14 and 2014/15 respectively, to study the effect of foliar application of ascorbic and salicylic acid (water spray, Asc 100 ppm, Asc 200 ppm, sal 100 ppm, sal $200 \mathrm{ppm}$, Asc $100 \mathrm{ppm}+$ sal 100 ppm, Asc $200 \mathrm{ppm}$ + sal 100 ppm, Asc 200 ppm + sal 200 ppm)under water deficit stress at identify growth stages (normal irrigation,water deficit stress attillering, heading and ripening stages) and its interaction on productivity of Misr1 wheat cultivar and some water relations.

Split plot design was used in the two experiments, where the main plots included the water deficit stresses treatments and foliar application of ascorbic and salicylic acid treatments wasallocated in the sub plots. The sub plot area was $10.5 \mathrm{~m} 2(3 \times 3.5 \mathrm{~m})$ in both seasons. Foliar application of ascorbic and salicylic acid were done at 50 and 65 days after sowing, The mineral nitrogen fertilizer was applied in the form of urea $(46.6 \% \mathrm{~N})$ in three doses, the first dose $(20 \%)$ at sowing, which was incorporated in dry soil, the second dose $(40 \%)$ was applied at the first irrigation and the third dose (40\%) at the second irrigation. Before the sowing, the experimental soil was fertilized with $150 \mathrm{~kg} / \mathrm{fed}$. of calcium super phosphate $(15.5 \%$ P2O5) during soil preparation. Before the soil preparation samples of soil was collected from $(0-30 \mathrm{~cm}$ layer) from the experimental sites in both seasons to for soil analysis which presented in Table (1).

Table 1. Soil analysis of the field experimental soil.

\begin{tabular}{|c|c|c|c|c|c|c|c|c|c|}
\hline \multirow{2}{*}{ Season } & \multirow{2}{*}{$E C_{e}(d S / m)$} & \multirow{2}{*}{$\mathbf{p H}$} & \multicolumn{3}{|c|}{ Available (ppm) } & \multicolumn{3}{|c|}{ Particle size distribution (\%) } & \multirow{2}{*}{ Texture clas } \\
\hline & & & $\mathbf{N}$ & $\mathbf{P}$ & $\mathbf{K}$ & sand & silt & clay & \\
\hline $\begin{array}{l}2013 / 14 \\
2014 / 15\end{array}$ & $\begin{array}{l}1.97 \\
191\end{array}$ & $\begin{array}{l}7.79 \\
7.96\end{array}$ & $\begin{array}{l}20.12 \\
2058\end{array}$ & $\begin{array}{l}10.64 \\
1087\end{array}$ & 341 & 21.1 & 27.1 & 51.8 & clayey \\
\hline
\end{tabular}

Seed of the wheat cultivar Misr 1was sown at $22^{\text {th }}$ and $27^{\text {th }}$ of November in the first and second seasons, respectively. The preceding crop was corn in the two growing seasons. Seed was uniformly broadcasted at the rate of $60 \mathrm{~kg} / \mathrm{fed}$. The other cultural practices were applied as recommended by the Ministry of Agriculture.

At ripening stage the following traits were recorded: plant height $(\mathrm{cm})$ and flag leaf area $\left(\mathrm{cm}^{2}\right)$. Ten flag leaves from each plot were collected when the flag leaf was fully expanded to measure flag leaf area by Leaf Area Meter (Li-Cor 3100, Lambda Instruments Co., USA). Chlorophyll a and b concentrations as $\mathrm{mg} / \mathrm{g}$ fresh weight were done according to Lichtenthaler (1987). Leaves samples (0.5 g) were homogenized with acetone $(90 \% \mathrm{v} / \mathrm{v})$, filtered and made up to a final volume of $50 \mathrm{ml}$. Chlorophyll concentration was calculated spectrophotometerically from absorbance of extract at 663 and $645 \mathrm{~nm}$.At harvest, the following traits were determined: spike length $(\mathrm{cm})$, number of spikes $/ \mathrm{m}^{2}$, number of grains /spike, grain weight $(\mathrm{g})$

/spik, weight of 1000-grains (g), grain yield (t/fed.) and straw yield ( $\mathrm{t} /$ fed.).

- Productivity of irrigation water (PIW), Field water use efficiency $\left(\mathrm{kg} \mathrm{m}^{-3}\right)$ :

PIWis considered an evaluation parameter of yield per unit of applied water.

PIW = Yield ( $\mathrm{kg} /$ feddan $) /$ Applied water $\left(\mathrm{m}^{3} /\right.$ feddan $)$.

- Water productivity index (WP), Crop water use efficiency $\left(\mathrm{Kg} \mathrm{m}^{-3}\right)$ :

WP as a measurement used to clarify variations in yield due to water consumptive use as it calculated according to Michael (1978) as follows:

$W P=$ Yield (kg/feddan) $/$ Water consumptive use ( $\mathrm{m}^{3} /$ feddan).

The analysis of variance was carried out according to Gomez and Gomez (1984) for all collected data. Treatment means were compared by Duncan's Multiple Range test according to Duncan (1955). All statistical analysis was performed using analysis of variance technique by means of "MSTATC" computer software package. 


\section{RESULTS AND DISCUSSION}

\section{A. Growth characters:}

Chlorophyll a, chlorophyll b, plant height, and flag leaf area of wheat at ripening stage as affected by foliar application of ascorbic and salicylic acid as well as water deficit stress at identify growth stage treatments during 2013/14 and 2014/15 seasons are presented in Table (2).

Data in table (2) show that water deficit stress at different growth stage showed that a significant differences in chlorophyll $\mathrm{a}$ and $\mathrm{b}$ in both seasons. Normal irrigation recorded the highest values of chlorophyll $\mathrm{a}$ and $\mathrm{b}$ compared with the other water deficit stress treatments without significantly differences with water deficit stress at heading and ripening stages in case of chlorophyll a in both seasons. The lowest values of chlorophyll $\mathrm{a}$ and $\mathrm{b}$ resulted from water deficit stress attillering stage in both seasons. Plant height and flag leaf area recorded the highest values under normal irrigation followed by the treatment of water deficit stress atripening stage in both seasons, without significant difference between the effect of normal irrigation treatment and water deficit stress atripening stage in respect to plant height. The lowest values of plant height and flag leaf area were recorded at water deficit stress attillering stage. These results were corresponded with those findings byAmin, et al., 2009, Abdalla, 2011 and Azadeh et al., 2014, which reported that plant growth reduced by water deficit stress through affecting various physiological and biochemical processes, such as photosynthesis, translocation, nutrient metabolism and growth promoters.

Table 2. Chlorophyll a, Chlorophyll b, flag leaf area $\left(\mathrm{cm}^{2}\right)$ and plant height $(\mathrm{cm})$ of wheat as affected by foliar application of ascorbic and salicylic acid under water deficit stress at identify growth stage treatments and their interaction during 2013/14 and 2014/15 seasons.

\begin{tabular}{|c|c|c|c|c|c|c|c|c|}
\hline \multirow{2}{*}{ Treatment } & \multicolumn{2}{|c|}{ Chlorophyll a } & \multicolumn{2}{|c|}{ Chlorophyll b } & \multicolumn{2}{|c|}{ Flage leaf area $\left(\mathrm{cm}^{2}\right)$} & \multicolumn{2}{|c|}{ Plant height (cm) } \\
\hline & 2013/14 & 2014/15 & $2013 / 14$ & $2014 / 15$ & $2013 / 14$ & $2014 / 15$ & $2013 / 14$ & $2014 / 15$ \\
\hline \multicolumn{9}{|c|}{ Water deficit stress(W.S): } \\
\hline Normal irrigation & $3.50 \mathrm{a}$ & $3.56 \mathrm{a}$ & $1.87 \mathrm{a}$ & $1.95 \mathrm{a}$ & $131.77 \mathrm{a}$ & $134.71 \mathrm{a}$ & $114.49 \mathrm{a}$ & $116.12 \mathrm{a}$ \\
\hline W.S at tillering & $3.07 \mathrm{~b}$ & $3.05 \mathrm{~b}$ & $1.35 \mathrm{~d}$ & $1.14 \mathrm{~d}$ & $118.01 \mathrm{c}$ & $119.34 \mathrm{~b}$ & $101.49 \mathrm{c}$ & $104.55 \mathrm{~d}$ \\
\hline W.S at heading & $3.42 \mathrm{a}$ & $3.24 \mathrm{a}$ & $1.61 \mathrm{c}$ & $1.57 \mathrm{c}$ & $118.89 \mathrm{bc}$ & $119.37 \mathrm{~b}$ & $108.18 \mathrm{~b}$ & $107.89 \mathrm{c}$ \\
\hline W.S at ripening & $3.45 \mathrm{a}$ & $3.41 \mathrm{a}$ & $1.79 \mathrm{~b}$ & $1.77 \mathrm{~b}$ & $120.05 \mathrm{~b}$ & $119.77 \mathrm{~b}$ & $113.59 \mathrm{a}$ & $113.61 \mathrm{~b}$ \\
\hline F-test & $* *$ & $* *$ & $* *$ & $* *$ & $* *$ & $* *$ & $* *$ & $* *$ \\
\hline \multicolumn{9}{|c|}{ Antioxidant: } \\
\hline Water (control) & $2.87 \mathrm{~d}$ & $2.79 \mathrm{~d}$ & $1.52 \mathrm{f}$ & $1.51 \mathrm{e}$ & $115.79 \mathrm{e}$ & $117.83 \mathrm{e}$ & $102.26 \mathrm{e}$ & $105.36 \mathrm{c}$ \\
\hline Asc $100 \mathrm{ppm}$ & $3.15 \mathrm{c}$ & $3.19 \mathrm{c}$ & $1.59 \mathrm{e}$ & $1.61 \mathrm{~d}$ & $120.35 \mathrm{~d}$ & $121.47 \mathrm{~d}$ & $107.90 \mathrm{~d}$ & $108.40 \mathrm{~b}$ \\
\hline Asc $200 \mathrm{ppm}$ & $3.26 \mathrm{c}$ & $3.17 \mathrm{c}$ & $1.61 \mathrm{de}$ & $1.64 \mathrm{~cd}$ & $121.18 \mathrm{~cd}$ & $123.28 \mathrm{c}$ & $108.29 \mathrm{~cd}$ & $110.26 \mathrm{ab}$ \\
\hline sal 100ppm & $3.24 \mathrm{c}$ & $3.18 \mathrm{c}$ & $1.68 \mathrm{bc}$ & $1.70 \mathrm{bc}$ & $121.90 \mathrm{bcd}$ & $123.01 \mathrm{~cd}$ & $110.83 \mathrm{ab}$ & $111.31 \mathrm{a}$ \\
\hline sal 200 ppm & $3.26 \mathrm{c}$ & $3.23 \mathrm{c}$ & $1.65 \mathrm{~cd}$ & $1.65 \mathrm{~cd}$ & $121.93 \mathrm{bcd}$ & $122.80 \mathrm{~cd}$ & $110.24 \mathrm{bc}$ & $111.17 \mathrm{a}$ \\
\hline Asc $100 \mathrm{ppm}+$ sal $100 \mathrm{ppm}$ & $3.62 \mathrm{~b}$ & $3.55 \mathrm{~b}$ & $1.73 \mathrm{ab}$ & $1.73 \mathrm{~b}$ & $122.84 \mathrm{bc}$ & $123.67 \mathrm{c}$ & $111.28 \mathrm{ab}$ & $112.12 \mathrm{a}$ \\
\hline Asc $200 \mathrm{ppm}+$ sal $100 \mathrm{pp}$ & $3.76 \mathrm{a}$ & $3.68 \mathrm{ab}$ & $1.73 \mathrm{ab}$ & $1.74 \mathrm{~b}$ & $124.04 \mathrm{~b}$ & $125.87 \mathrm{~b}$ & $112.02 \mathrm{ab}$ & $112.68 \mathrm{a}$ \\
\hline Asc $200 \mathrm{ppm}+$ sal $200 \mathrm{ppm}$ & $3.71 \mathrm{ab}$ & $3.72 \mathrm{a}$ & $1.76 \mathrm{a}$ & $1.80 \mathrm{a}$ & $129.3 \mathrm{a}$ & $128.47 \mathrm{a}$ & $112.67 \mathrm{a}$ & $113.01 \mathrm{a}$ \\
\hline F-test & $* *$ & $* *$ & $* *$ & $* *$ & $* *$ & $* *$ & $* *$ & $* *$ \\
\hline Interaction & $* *$ & $* *$ & $* *$ & ** & ** & ** & ** & Ns \\
\hline
\end{tabular}

At all tables:*, $* *$ and Ns indicate $\mathrm{p}<0.05,<0.01$ and not significant, respectively. Means of each treatment followed by the same letter are not significantly different at $5 \%$ level, according to Duncan's multiple range tests.

Asc 100 ppm and Asc 200 ppm (Ascorbic acid at rate 100 and $200 \mathrm{ppm}$ ) and sal 100ppmand sal $200 \mathrm{ppm}$ (salicylic acid at rate 100 and $200 \mathrm{ppm}$ ).

With regard tothe effect of foliar application of ascorbic and salicylic acidon Chlorophyll a, chlorophyll b, flag leaf areaand plant height, Data presented in table (2) revealed that the combination between ascorbic acid and salicylic acid at rate of $200 \mathrm{ppm}$ of each other recorded the greatest values at all previous characters without significant differences withthe treatment of Asc $200 \mathrm{ppm}+$ Sal 100 $\mathrm{ppm}$ in most cases in the two seasons of study. The most of antioxidant treatment showed a significant increase in plant height compared with water spray treatment. Such effect of ascorbic and salicylic acid may be attributed to the important role, which the antioxidant plays against oxidative stress, Ascorbic acid plays an important role in photosynthesis.The promoting effects of ascorbic and salicylic acid on Chlorophyll a, chlorophyll b, flag leaf area and plant height of wheat were reported by Abdelaal, (2015a), which found that application of SA led to increase in wheat plant height and chlorophyll $a$ and $b$ concentrations under drought stress conditions. The increase in chlorophyll concentrations may be due to the role of SA through improvement the physiological processes such as photosynthesis and antioxidant activity as well as leaves longevity, Malik et al (2015) reported that ascorbic acid application under drought led to overcome adverse effects of oxidative stress by maintaining growth, Amin et al (2008) reported that foliar application of wheat plants (Triticumaestivum L.) cv. Gemmiza 10 with salicylic acid at the rate of $100 \mathrm{mg} \mathrm{l}^{-1}$ combined with ascorbic acid at 200 or $400 \mathrm{mg} \mathrm{l}^{-1}$ were more effective in increasing growth characters, yield and its components in addition to photosynthetic pigments content in the leaves compared with other treatments or untreated plants.

The interaction between foliar application of ascorbic and salicylic acid and water deficit stress at identify growth stage treatments show a significant effect on Chlorophyll a, Chlorophyll b, flag leaf area and plant height in both seasons, except that plant height in the second season, table (2).

\section{B. Yield and its components:}

Data presented in Tables (3, 4 and 5) show the effect of foliar application of ascorbic \& salicylic acid and water deficit stress at identify growth stage treatments on 
yield and its components of wheat during 2013/14 and $2014 / 15$ seasons as well as their interaction.

The data show that water deficit stress at different growth stages showed significant differences in spike length, number of spike $/ \mathrm{m}^{2}$, numberof grains /spike, grain weight /spike and 1000 grain weight in both seasons. Normal irrigation recorded the highest values of all mentioned characters without significant differences with water deficit stress at heading and ripening stages in respect to spike length in the second season; with water stress at heading stage in respect to no. of grains/spike in the second seasons as well as with water stress at tillering stage in respect to grain weight/spike in the first season. The lowest values of these characters were recorded under water stress at ripening stage in most cases in both seasons. These findings were in conformity with those obtained by Amin, et al., (2009), Abdalla, (2011), Bakry et al., (2013) and Azadeh et al., (2014) which reported that water deficit stress reduces plant growth by affecting various physiological and biochemical processes, such as photosynthesis, respiration, translocation, ion uptake, carbohydrates, nutrient metabolism and growth promoters.

The results in Table (3 and 4) show that the effects of foliar application of ascorbic and salicylic acid on spike length, number of spike/ $/ \mathrm{m}^{2}$, number of grain /spike, grain weight /spike and 1000 grain weight were significant in the two seasons of study. Data presented in the two tables showed that the combination between ascorbic acid and salicylic acid at the rate of $200 \mathrm{ppm}$ recorded the highest values of each other all previous characters in both seasons, without significant differences with other foliar application treatments in some cases of these characters. Such effect of antioxidant may be attributed to the important role in photosyn thesis. The promoting effects of ascorbic and salicylic acid on spike length, number of spike $/ \mathrm{m}^{2}$, number of grains /spike, grain weight /spike and 1000 grain weight of wheat were reported by several of authors, which explain the effects of antioxidants on growth characters and its reversion on yield components as soon as Abdelaal (2015a)which reported that application of SA increased growth characters under drought stress conditions. The increment in growth characters may be due to the active role of SA in increasing nutrient contents in plant as well as improvement the physiological processes such as photosynthesis and antioxidant activity as well as leaves longevity, Malik et al. (2015) reported that ascorbic acid application under drought to overcome adverse effects of oxidative stress by maintaining growth, Amin et al. (2008) reported that foliar application of wheat plants Triticumaestivum L.) cv. Gemmiza 10 with salicylic acid at $100 \mathrm{mg} \mathrm{l}^{-1}$ combined with ascorbic acid at 200 or $400 \mathrm{mg} \mathrm{l}^{-1}$ were more effective in increasing growth characters, yield and its components in addition to photosynthetic pigments content the leaves compared with other treatments or untreated plants.

Table 3. Spike length (cm), Number of spike/ $\mathrm{m}^{2}$, Number of grains /spike and grain weight /spike (g) of wheat as affected by foliar application of ascorbic and salicylic acid under water deficit stress at identify growth stage treatments and their interaction during 2013/14 and 2014/15 seasons.

\begin{tabular}{|c|c|c|c|c|c|c|c|c|}
\hline \multirow[t]{2}{*}{ Treatment } & \multicolumn{2}{|c|}{ Spike length(cm) } & \multicolumn{2}{|c|}{ No. of spikes/m² } & \multicolumn{2}{|c|}{ No. of grains /spike } & \multicolumn{2}{|c|}{ Grain wt /spik(g) } \\
\hline & $2013 / 14$ & $2014 / 15$ & $2013 / 14$ & $2014 / 15$ & $2013 / 14$ & $2014 / 15$ & $2013 / 14$ & $2014 / 15$ \\
\hline \multicolumn{9}{|c|}{ Water deficit stress(W.S): } \\
\hline Normal irrigation & $15.72 \mathrm{a}$ & $15.51 \mathrm{a}$ & $397.50 \mathrm{a}$ & $399.21 \mathrm{a}$ & $85.54 \mathrm{a}$ & $82.83 \mathrm{a}$ & $3.51 \mathrm{a}$ & $3.57 \mathrm{a}$ \\
\hline W.S at tillering & $11.75 \mathrm{~d}$ & $12.97 \mathrm{~b}$ & $357.29 \mathrm{c}$ & $364.88 \mathrm{~d}$ & $63.13 \mathrm{~d}$ & $62.96 \mathrm{c}$ & $3.34 \mathrm{a}$ & $2.61 \mathrm{~d}$ \\
\hline W.S at heading & $15.25 \mathrm{~b}$ & $15.06 \mathrm{a}$ & $388.63 \mathrm{~b}$ & $384.33 \mathrm{~b}$ & $81.50 \mathrm{~b}$ & $79.04 \mathrm{a}$ & $2.83 \mathrm{~b}$ & $3.35 \mathrm{~b}$ \\
\hline W.S at ripening & $13.59 \mathrm{c}$ & $14.89 \mathrm{a}$ & $353.83 \mathrm{c}$ & $371.88 \mathrm{c}$ & $79.25 \mathrm{c}$ & $71.33 \mathrm{~b}$ & $2.73 \mathrm{~b}$ & $3.09 \mathrm{c}$ \\
\hline F-test & $* *$ & $* *$ & $* *$ & $* *$ & $* *$ & $* *$ & $* *$ & $* *$ \\
\hline \multicolumn{9}{|c|}{ Antioxidant: } \\
\hline Water (control) & $12.83 \mathrm{~d}$ & $13.05 \mathrm{f}$ & $351.00 \mathrm{e}$ & $346.58 \mathrm{e}$ & $69.17 \mathrm{e}$ & $66.00 \mathrm{c}$ & $2.80 \mathrm{~d}$ & $2.82 \mathrm{f}$ \\
\hline Asc $100 \mathrm{ppm}$ & $13.55 \mathrm{c}$ & $14.018 \mathrm{e}$ & $357.83 \mathrm{e}$ & $362.33 \mathrm{~d}$ & $73.58 \mathrm{~d}$ & $70.92 \mathrm{bc}$ & $2.97 \mathrm{c}$ & $2.95 \mathrm{ef}$ \\
\hline Asc $200 \mathrm{ppm}$ & $13.48 \mathrm{c}$ & $14.48 \mathrm{de}$ & $366.08 \mathrm{~d}$ & $362.58 \mathrm{~d}$ & $76.75 \mathrm{c}$ & $73.58 \mathrm{ab}$ & $3.01 \mathrm{c}$ & $3.03 \mathrm{e}$ \\
\hline sal 100ppm & $14.26 \mathrm{~b}$ & $14.79 \mathrm{~cd}$ & $378.33 \mathrm{bc}$ & $389.92 \mathrm{bc}$ & $78.50 \mathrm{bc}$ & $76.67 \mathrm{ab}$ & $3.12 \mathrm{bc}$ & $3.22 \mathrm{~cd}$ \\
\hline sal $200 \mathrm{ppm}$ & $13.55 \mathrm{c}$ & $14.43 \mathrm{de}$ & $374.17 \mathrm{c}$ & $383 \mathrm{c}$ & $78.50 \mathrm{bc}$ & $74.67 \mathrm{ab}$ & $3.08 \mathrm{bc}$ & $3.09 \mathrm{de}$ \\
\hline Asc $100 \mathrm{ppm}+$ sal $100 \mathrm{ppm}$ & $14.68 \mathrm{~b}$ & $15.08 \mathrm{bc}$ & $392.50 \mathrm{a}$ & $394.42 \mathrm{ab}$ & $79.42 \mathrm{abc}$ & $75.83 \mathrm{ab}$ & $3.22 \mathrm{ab}$ & $3.28 \mathrm{bc}$ \\
\hline Asc $200 \mathrm{ppm}+\mathrm{sal} 100 \mathrm{ppm}$ & $14.91 \mathrm{ab}$ & $15.33 \mathrm{ab}$ & $385.25 \mathrm{ab}$ & $397.17 \mathrm{ab}$ & $80.92 \mathrm{ab}$ & $76.42 \mathrm{ab}$ & $3.29 \mathrm{a}$ & $3.38 \mathrm{ab}$ \\
\hline Asc $200 \mathrm{ppm}+\mathrm{sal} 200 \mathrm{ppm}$ & $15.36 \mathrm{a}$ & $15.79 \mathrm{a}$ & $389.33 \mathrm{a}$ & $404.58 \mathrm{a}$ & $82.00 \mathrm{a}$ & $78.25 \mathrm{a}$ & $3.31 \mathrm{a}$ & $3.44 \mathrm{a}$ \\
\hline F-test & $* *$ & $* *$ & $* *$ & $* *$ & $* *$ & $* *$ & $* *$ & $* *$ \\
\hline Intensction & & ns & $* * \mathrm{~ns}$ & $* *$ & ns & $\mathrm{ns}$ & ns & $\mathrm{ns}$ \\
\hline
\end{tabular}

The interaction between water stress treatment and foliar application of ascorbic and salicylic acid significantly affected number of spike $/ \mathrm{m}^{2}$ in both seasons and 1000 grain weight only in the first season, tables (3 and 4).

Data presented in table (4) show that water deficit stress at different growth stages recorded a highly significant differences in grain and straw yields in both seasons. Normal irrigation treatment recorded the highest values of grain and straw yields compared with the other water deficit stress treatments without significant differences with the treatment of water deficit stress at heading stage in respect of grain yield character in the first season. The treatment of water deficit stress atripening stage followed the normal irrigation in grain and straw yields in both seasons without significant differences with the treatment of water deficit stress at heading stage in most cases. The lowest values of grain and straw yields were obtained from the treatment of water deficit stress attillering stage in both seasons. Amin, et al., (2009), Abdalla, (2011), Bakry et al., (2013) and Azadeh et al., (2014)reported that water deficit stress reduced plant growth by affecting various physiological and biochemical processes, such as photosynthesis, respiration, 
translocation, ion uptake, carbohydrates, nutrient metabolism and growth promoters, then it affect grain and straw yields of wheat. Shirazi et al. (2014) reported that the maximum grain yield was obtained from application of the tow irrigation treatments $(100 \mathrm{~mm}$ at $30 \mathrm{DAS}+100 \mathrm{~mm}$ at 45 DAS).

Foliar application of ascorbic and salicylic acid significantly affected grain and straw yields in both seasons as shown in Table (4). The combinations between ascorbic acid and salicylic acid at the rate of $200 \mathrm{ppm}$ of each other recorded the greatest grain and straw yields compared with the other treatments, without significant differences with the combination between ascorbic acid and salicylic at the rate of $200 \mathrm{ppm}+100 \mathrm{ppm}$, then the combination at the rate of $100 \mathrm{ppm}+100 \mathrm{ppm}$. The most of antioxidant treatment showed an increase ingrain and straw yields compared with water spray treatment (control), which recorded the lowest values. Such favorable effect of antioxidant on yield might have been resulted from the important role in photosynthesis, which increased vegetative growth under drought stress conditions, as soon as photosynthetic area, which resulted in more assimilates products and consequently increased dry matter accumulation and translocation of more photosynthesis to grain. These findings were in conformity with those obtained by Abdelaal (2015a)which reported that application of SA led to an increase in growth characters under drought stress conditions. The increment in growth characters may be due to the active role of SA in increasing nutrient contents in plants as well as improvement the physiological processes such as photosynthesis and antioxidant activity as well as leaves longevity. Malik et al. (2015) reported that ascorbic acid application under drought to overcome adverse effects of oxidative stress by maintaining growth. Amin et al. (2008) reported that foliar application of wheat plants (Triticumaestivum L.) cv. Gemmiza 10 with salicylic acid at the rate of $100 \mathrm{mg} \mathrm{l}^{-1}$ combined with ascorbic acid at the rate of 200 or $400 \mathrm{mg} \mathrm{l}^{-1}$ were more effective in increasing growth characters, yield and its components in addition to photosynthetic pigments content in the leaves compared with other treatments or untreated plants.

The interaction between water deficit stress at different growth stages and foliar application of ascorbic and salicylic acid significantly affected grain and straw yields during 2013/14 and 2014/15 seasons. as shown in table (4). Data presented in table (5) show that the different combinations of ascorbic and salicylic acid under normal irrigation treatment recorded the highest grain yield in both seasons. followed by the interaction between the treatment of water deficit stress atripening stage with the combination of ascorbic acid (200 ppm) and salicylic acid (200 ppm) in both seasons and the interaction between the treatment of water deficit stress at heading stage and the different combinations of ascorbic and salicylic acid in second season compared with the other treatments, the lowest values of grain yield were obtained from the interaction between water spray treatment and all water deficit stress treatments in both seasons. Shirazi et al, (2014) reported that the maximum grain yield was obtained from application of $200 \mathrm{~mm}$ in tow irrigation (100 mm at $30 \mathrm{DAS}+100 \mathrm{~mm}$ at $45 \mathrm{DAS})$, Bakry et al., (2013) found that water irrigation requirement of (80\% IR) produced high grain yield per fad. and insignificantly out yielded the water irrigation requirements of (100\% IR). Increasing foliar application levels of ascorbic acid from 0 up to $300 \mathrm{mg} / \mathrm{l}$ significantly increased grain and straw yields per plant and per fad. as well as plant height, spike length and seed index.

Table 4. 1000 grain weight (g), Grain yield (kg/fed) and Straw yield (ton/fed.) of wheat as affected by foliar application of ascorbic and salicylic acid under water deficit stress at identify growth stage treatments and their interaction during 2013/14 and 2014/15 seasons.

\begin{tabular}{cccc}
\hline Treatment & $\begin{array}{c}\text { 1000 grain } \\
\text { weight }(\text { gm) }\end{array}$ & $\begin{array}{c}\text { Grain yeild } \\
(\mathbf{k g} / \text { fed) }\end{array}$ & $\begin{array}{c}\text { Straw yeild } \\
\text { (t./fed.) }\end{array}$ \\
\cline { 2 - 3 } & 2013/12014/1 2013/1 2014/1 2013/ 2014/1 \\
\hline
\end{tabular}

Normal irrigation 45.9748 .093025 .003101 .53 .41 a $3.77 \mathrm{a}$ W.S at tillering $\quad 41.33 \quad 34.472597 .882448 .42 .81 \mathrm{c} 2.70 \mathrm{c}$ W.S at heading $\quad 44.5642 .862967 .442649 .93 .27 \mathrm{~b} 3.23 \mathrm{~b}$ W.S at ripening $\quad 34.75 \quad 32.992878 .692520 \quad 3.23$ b 2.87 \begin{tabular}{lllllll}
\hline F-test & $* *$ & $* *$ & $* *$ & $* *$ & $* *$ & $* *$ \\
\hline
\end{tabular} \begin{tabular}{l} 
Antioxidant: \\
\hline Water (control) 39.2236 .472611 .252502 .82 .75 e $2.81 \mathrm{~d}$
\end{tabular} $\begin{array}{llllll}\text { Asc } 100 \mathrm{ppm} & 39.70 & 37.95 & 2630.882551 .1 & 2.89 & 2.91\end{array}$ Asc 200 ppm $\quad 41.1738 .492686 .002584 .13 .04 \quad 2.97 \mathrm{c}$ sal 100ppm $\quad 41.1839 .982941 . .12739 .33 .27$ b 3.18 b sal 200 ppm $\quad 41.53 \quad 39.512867 .382684 .53 .213 .18$ b Asc $100 \mathrm{ppm}+\mathrm{sal} \quad 42.48 \quad 40.35 \quad 3022.25 \quad 2782 \quad 3.38 \quad 3.34 \mathrm{a}$ Asc $200 \mathrm{ppm}+$ sal $43.53 \quad 41.703072 .882775 .9 \quad 3.38 \quad 3.32 \mathrm{a}$ Asc $200 \mathrm{ppm}+$ sal $44.44 \quad 42.363106 .252820 .13 .52$ a 3.44 a

\begin{tabular}{lllllll}
\hline F-test & $* *$ & $* *$ & $* *$ & $* *$ & $* *$ & $* *$ \\
\hline Interaction & $* *$ & ns & $*$ & $*$ & $*$ & $* *$
\end{tabular}

Table 5. Grain yieldkg/fed. of wheat as affected by the interaction between foliar application of ascorbic \& salicylic acid and water deficit stress at identify growth stage treatment during 2013/14 and 2014/15 seasons.

\begin{tabular}{|c|c|c|c|c|c|c|c|c|}
\hline \multirow{2}{*}{$\begin{array}{l}\text { Water deficit stress (W.S) } \\
\text { Antioxedant }\end{array}$} & \multicolumn{2}{|c|}{ Normal irrigation } & \multicolumn{2}{|c|}{ W.S at tillering } & \multicolumn{2}{|c|}{ W.S at heading } & \multicolumn{2}{|c|}{ W.S at ripening } \\
\hline & $2013 / 14$ & $2014 / 15$ & $2013 / 14$ & $2014 / 15$ & $2013 / 14$ & $2014 / 15$ & $2013 / 14$ & $2014 / 15$ \\
\hline Water (control) & $2669.0 \mathrm{ij}$ & $2731.0 \mathrm{cde}$ & $2438.0 \mathrm{kl}$ & $2303.0 \mathrm{i}$ & $2616.5 \mathrm{ijk}$ & $2566.0 \mathrm{e}-\mathrm{i}$ & 2721.5 hij & $2411.0 \mathrm{ghi}$ \\
\hline Asc 100 ppm & $2708.5 \mathrm{hij}$ & $2881.0 \mathrm{~cd}$ & $2371.0 \quad 1$ & $2306.5 \mathrm{i}$ & $2655.0 \mathrm{ij}$ & $2575.5 \mathrm{e}-\mathrm{i}$ & $2789.0 \mathrm{f}-\mathrm{i}$ & $2441.5 \mathrm{f}-\mathrm{i}$ \\
\hline Asc $200 \mathrm{ppm}$ & $2799.0 \mathrm{f}-\mathrm{i}$ & $2931.5 \mathrm{bc}$ & 2403.51 & $2347.0 \mathrm{hi}$ & $2743.5 \mathrm{~g}-\mathrm{j}$ & 258 & $2798.0 \mathrm{f}-\mathrm{i}$ & 2477.0 e-i \\
\hline sal 100ppm & $3131.5 \mathrm{a}-\mathrm{d}$ & $3275.0 \mathrm{a}$ & $2664.0 \mathrm{ij}$ & $2466.5 \mathrm{e}-\mathrm{i}$ & $3070.0 \mathrm{~b}-\mathrm{e}$ & $2693.0 \mathrm{c}-\mathrm{f}$ & 2899.0 e-h & $2522.5 \mathrm{e}-\mathrm{i}$ \\
\hline sal 200 ppm & $3044.0 \mathrm{~b}-\mathrm{e}$ & $3136.0 \mathrm{ab}$ & $2556.0 \mathrm{jkl}$ & $2456.0 \mathrm{e}-\mathrm{i}$ & 2984.5 c-f & $2647.0 \mathrm{~d}-\mathrm{g}$ & 2885.0 e-h & $2499.0 \mathrm{e}-\mathrm{i}$ \\
\hline Asc $100 \mathrm{ppm}+$ sal $100 \mathrm{ppm}$ & $3251.5 \mathrm{ab}$ & $3356.5 \mathrm{a}$ & 2733.5 hij & $2530.0 \mathrm{e}-\mathrm{i}$ & $3187.5 \mathrm{abc}$ & $2703.0 \mathrm{c}-\mathrm{f}$ & 2916.5 e-h & $2538.5 \mathrm{e}-\mathrm{i}$ \\
\hline Asc $200 \mathrm{ppm}+\mathrm{sal} 100 \mathrm{ppm}$ & $3305.5 \mathrm{a}$ & $3218.0 \mathrm{a}$ & $2795.0 \mathrm{f}-\mathrm{i}$ & $2564.5 \mathrm{e}-\mathrm{i}$ & $3240.5 \mathrm{ab}$ & $2710.5 \mathrm{c}-\mathrm{f}$ & $2950.5 \mathrm{~d}-\mathrm{g}$ & $2610.5 \mathrm{e}-\mathrm{h}$ \\
\hline Asc 200 ppm + sal 200 ppm & $3291.0 \mathrm{a}$ & $3283.0 \mathrm{a}$ & $2822.0 \mathrm{f}-\mathrm{i}$ & $2614.0 \mathrm{e}-\mathrm{h}$ & $3242.0 \mathrm{ab}$ & 2723.5 cde & 3070.0 b-e & $2660.0 \mathrm{~d}-\mathrm{g}$ \\
\hline
\end{tabular}


Table 6. Water applied $\left(\mathrm{m}^{3} /\right.$ fed.), water consumption $\left(\mathrm{m}^{3} /\right.$ fed.), Productivity of irrigation water $\left(\mathrm{kg} / \mathrm{m}^{3}\right)$, and water productivity index $\left(\mathrm{kg} / \mathrm{m}^{3}\right)$ of wheat as affected by foliar application of ascorbic and salicylic acid under water deficit stress at identify growth stages during 2013/14 and 2014/15 seasons.

\begin{tabular}{|c|c|c|c|c|c|c|c|c|}
\hline \multirow[t]{2}{*}{ Treatment } & \multicolumn{2}{|c|}{$\begin{array}{c}\text { Water applied } \\
\left(\mathrm{m}^{3} / \text { fed. }\right)\end{array}$} & \multicolumn{2}{|c|}{$\begin{array}{c}\text { Water consumtion } \\
\left(\mathrm{m}^{3} / \mathrm{fed} .\right)\end{array}$} & \multicolumn{2}{|c|}{$\begin{array}{c}\text { Productivity of } \\
\text { irrigation water (PIW) }\end{array}$} & \multicolumn{2}{|c|}{$\begin{array}{c}\text { Water productivity } \\
\text { index (WP) }\end{array}$} \\
\hline & $2013 / 14$ & $2014 / 15$ & $2013 / 14$ & $2014 / 15$ & $2013 / 14$ & $2014 / 15$ & $2013 / 14$ & $2014 / 15$ \\
\hline \multicolumn{9}{|c|}{ Water deficit stress(W.S): } \\
\hline Normal irrigation & 1965.08 & 2353.41 & 1287.03 & 1254.46 & 1.539375 & 1.318 & 2.350 & 2.472 \\
\hline W.S at tillering & 1697.41 & 1736.30 & 1113.06 & 1064.98 & 1.53 & 1.4 & 2.334 & 2.299 \\
\hline W.S at heading & 69.25 & 755.92 & 1209.10 & 853.88 & 1.5 & & & 3.103 \\
\hline W.S at ripening & 1850.50 & 1709.05 & 1215.34 & 847.99 & 1.555625 & 1.475 & 2.369 & 2.972 \\
\hline \multicolumn{9}{|c|}{ Antioxidant: } \\
\hline Water (control) & 1744.32 & 1881.45 & 1173.86 & 977.66 & 1.497 & 1.330 & 2.225 & 2.560 \\
\hline Asc $100 \mathrm{ppm}$ & 1714.21 & 1875.46 & 1157.96 & 982.51 & 1.53475 & 1.360 & 2.272 & 2.597 \\
\hline Asc $200 \mathrm{ppm}$ & 1723.45 & 1862.08 & 1143.47 & 986.96 & 1.5585 & 1.388 & 2.349 & 2.618 \\
\hline salicylic 100ppm & 1918.86 & 1945.18 & 1263.91 & 1030.78 & 1.53275 & 1.408 & 2.327 & 2.658 \\
\hline salicylic 200 ppm & 1845.75 & 1866.83 & 1199.49 & 975.03 & 1.553 & 1.438 & 2.391 & 2.753 \\
\hline Asc $100 \mathrm{ppm}+$ sal100 ppm & 1949.21 & 1894.45 & 1252.88 & 1002.52 & 1.5505 & 1.469 & 2.412 & 2.775 \\
\hline Asc $200 \mathrm{ppm}+\mathrm{sal} 100 \mathrm{ppm}$ & 1947.33 & 1851.53 & 1231.74 & 978.46 & 1.578 & 1.499 & 2.495 & 2.837 \\
\hline Asc $200 \mathrm{ppm}+$ sal $200 \mathrm{ppm}$ & 1916.26 & 1842.00 & 1220.77 & 973.96 & 1.621 & 1.531 & 2.545 & 2.896 \\
\hline
\end{tabular}

\section{Water relations:}

Data of total water applied (m3/fed.), water consumption (m3/fed.), Productivity of irrigation water (PIW) and water productivity index (WP) in both seasons are presented in Table (7). The obtained results clearly show that the treatment of normal irrigation received the highest values of total water applied (m3/fed.) and water consumption (m3/fed.) while, the treatment of water deficit stress at heading and ripening stages recorded the greatest values of Productivity of irrigation water (PIW) and water productivity index (WP), These results are in accordance with those obtained by Bakry et al., (2013) study the effect of drought stress (100\% IR, $80 \%$ IR and $60 \%$ IR) on yield and irrigations water use efficiency of wheat they found that water irrigation requirement of (80\% IR) produced the highest irrigations water use efficiency and high grain yield per fad.

Table 7. Productivity of irrigation water (PIW) and water productivity index (WP) of wheat as affected by the interaction between foliar application of ascorbic and salicylic acid and the treatments of water deficit stress at identify growth stages during 2013/14 and 2014/15 seasons.

Productivity of irrigation water (PIW) (Kg m-3)

Water deficit stress

\begin{tabular}{|c|c|c|c|c|c|c|c|c|}
\hline \multirow{3}{*}{$\begin{array}{l}\text { Factors } \\
\text { Antioxidant }\end{array}$} & \multirow{2}{*}{\multicolumn{2}{|c|}{ Normal irrigation }} & \multirow{2}{*}{\multicolumn{2}{|c|}{ Drought at tillering }} & \multirow{2}{*}{\multicolumn{2}{|c|}{ Drought at heading }} & \multirow{2}{*}{\multicolumn{2}{|c|}{ Drought at ripening }} \\
\hline & & & & & & & & \\
\hline & 2013/14 & 2014/15 & 2013/14 & 2014/15 & 2013/14 & $2014 / 15$ & 2013/14 & $2014 / 15$ \\
\hline Water (control) & 1.493 & 1.223 & 1.454 & 1.327 & 1.526 & 1.38 & 1.515 & 1.391 \\
\hline Asc 100 & 1.562 & 1.254 & 1.461 & 1.350 & 1.587 & 1.427 & 1.529 & 1.410 \\
\hline Asc 200 & 1.544 & 1.258 & 1.506 & 1.380 & 1.653 & 1.514 & 1.531 & 1.399 \\
\hline sal 100 & 1.514 & 1.283 & 1.511 & 1.398 & 1.571 & 1.525 & 1.535 & 1.427 \\
\hline salc 200 & 1.516 & 1.276 & 1.577 & 1.420 & 1.563 & 1.556 & 1.558 & 1.500 \\
\hline Asc $100+$ sal 100 & 1.520 & 1.392 & 1.568 & 1.432 & 1.537 & 1.534 & 1.577 & 1.516 \\
\hline Asc $200+$ sal 100 & 1.576 & 1.414 & 1.573 & 1.457 & 1.571 & 1.571 & 1.592 & 1.555 \\
\hline Asc $200+$ sal 200 & 1.590 & 1.443 & 1.594 & 1.517 & 1.692 & 1.566 & 1.608 & 1.598 \\
\hline \multirow[t]{2}{*}{ Factors } & \multicolumn{8}{|c|}{$\begin{array}{c}\text { Water productivity index }\left(\mathrm{Kg} \mathrm{m}^{-3}\right) \\
\text { Water deficit stress }\end{array}$} \\
\hline & \multicolumn{2}{|c|}{ Normal irrigation } & \multicolumn{2}{|c|}{ Drought at tillering } & \multicolumn{2}{|c|}{ Drought at heading } & \multicolumn{2}{|c|}{ Drought at ripening } \\
\hline Antioxidant & $2013 / 14$ & $2014 / 15$ & 2013/14 & $2014 / 15$ & 2013/14 & $2014 / 15$ & $2013 / 14$ & 2014/15 \\
\hline Water (control) & 2.238 & 2.299 & 2.170 & 2.133 & 2.275 & 2.932 & 2.215 & 2.876 \\
\hline Asc 100 & 2.268 & 2.324 & 2.205 & 2.195 & 2.338 & 2.968 & 2.277 & 2.899 \\
\hline Asc 200 & 2.323 & 2.326 & 2.221 & 2.224 & 2.47 & 3.033 & 2.382 & 2.89 \\
\hline sal 100 & 2.329 & 2.397 & 2.283 & 2.256 & 2.312 & 3.045 & 2.384 & 2.932 \\
\hline sal200 & 2.385 & 2.597 & 2.364 & 2.330 & 2.433 & 3.153 & 2.380 & 2.933 \\
\hline Asc $100+$ sal 100 & 2.389 & 2.600 & 2.406 & 2.371 & 2.531 & 3.198 & 2.323 & 2.931 \\
\hline Asc $200+$ sal 100 & 2.409 & 2.589 & 2.433 & 2.398 & 2.574 & 3.247 & 2.563 & 3.114 \\
\hline Asc $200+$ sal 200 & 2.462 & 2.647 & 2.590 & 2.485 & 2.701 & 3.251 & 2.425 & 3.199 \\
\hline
\end{tabular}

Regarding to the effect of foliar application of ascorbic and salicylic acid on water relations in both seasons showing in Table (7). Data revealed that the combination between ascorbic (200 ppm) and salicylic acid (200) recorded the highest Productivity of irrigation water (PIW) and water productivity index
(WP) compared with the other treatments. Similar results were obtained by Malik et al(2015) reported that ascorbic acid application under drought to overcome adverse effects of oxidative stress by relative water content, osmotic adjustment through proline accumulation and by enhanced activity of antioxidant 
enzymes, Farjam et al(2015) showed that ascorbic acid application increased rate of biological water use efficiency significantly as compared with control plants Such effect of ascorbic and salicylic acid could be its involved in various physiological processes in plants, such as growth regulation, photosynthesis, nutrient uptake, plant water relations and mechanisms of plant resistance and tolerance to biotic and abiotic stresses which play a rolein the defense against oxidative stress.

Data presented in Table 8 showed that the effect of interaction between foliar application of ascorbic \& salicylic acid and the treatments of water deficit stress at identify growth stages on Productivity of irrigation water (PIW) and water productivity index (WP) during 2013/14 and 2014/15 seasons. It could be concluded that the combination between both salicylic and ascorbic acid with water deceit stress treatments recorded the highest values of Productivity of irrigation water (PIW) and water productivity index (WP) during 2013/14 and 2014/15 seasons compared with the other interaction. Similar results were obtained by Bakry et al., (2013) reported that the interaction between the water irrigation requirements of $(80 \%$ IR) and $(300 \mathrm{mg} / \mathrm{L})$ foliar application level of ascorbic acid gave the highest values of grain and yields per fad. and water use efficiency.

\section{REFERENCES}

Abdelaal, Kh. A.A (2015a). Effect of Salicylic acid and Abscisic acid on morpho-physiological and anatomical characters of faba bean plants (Viciafaba L.) under drought stress, J. Plant Production, Mansoura Univ., Egypt, 6 (11): 1771-1788.

Abdalla, M. M. (2011).Beneficial effects of diatomite on the growth, the biochemical contents and polymorphic DNA in Lupinusalbus plants grown under water deficit stress. Agric. Biol. J. North Amer. 2: 207-220.

Amin, A.A., E. M. Rashad and Fatma, A.E. Gharib (2008).Changes in Morphological, Physiological and Reproductive Characters of Wheat Plants as Affected by Foliar Application with Salicylic Acid and Ascorbic Acid. Australian Journal of Basic and Applied Sciences, 2(2):252-261, 2008.

Amin, B., G. Mahleghah, H. M. R. Mahmood and M. Hossein (2009).Evaluation of interaction effect of drought stress with ascorbate and salicylic acid on some of physiological and biochemical parameters in okra (Hibiscus esculentus L.). Res. J. Biol. Sci. 4: 380-387.

Amirkhan, M. S. A. Ahmad, H. U. R. Athar, and M. Ashraf, (2006).Interactive effect of foliarly applied ascorbic acid and salt stress on wheat (TriticumaestivumL.) at the seedling stage.Pakistan J. Bot. 38(5):1404-1414.

Azadeh, R., F. Maryam, S. Saeed (2014). The effects of seed priming by ascorbic acid on some morphological and biochemical aspects of rapeseed (Brassica napus L.) under drought stress condition .Int. J. Biosci, 4 (1):432-442.
Bakry, A. B, Abdelraouf, R. E and A. Ahmed (2013).Effect of drought stress and ascorbic acid foliar application on productivity and irrigation water use efficiency of wheat under newly reclaimed sandy soil. Elixir Agriculture, 57A: 14398-14403.

Cruz-Aquado, J.A., R. Rodes, I.P. Perez, and M. Dorado. (2000). Morphological characteristics and yield components associated with accumulation and loss of dry mass in the internodes of wheat. Field Crops Res. 66: 129-139.

Duncan, B.D. (1955) Multiple ranges and multiple FTest Biometrics, 11:1-42.

El-Housini, E. A., M. A. Ahmed, M. S. Hassanein and M. M. Tawfik (2014).Effect ofsalicylic acid (SA) on growth and quality of stevia (Stevia rebaudiana Bert.) under salt stress. Am. Eurasian J. Agric. Environ. Sci., 14: 275-281.

FAO (2014) FAO land and plant nutrition management service http:www.fao.org/ag/agl/agll/spush [Last accessed 25 April2014].

Farjam S., H. K. Arbat, A. Siosemardeh, M. Yarnia and A. Rokhzadi (2015) Effects of salicylic and ascorbic acid applications on growth, yield, water use efficiency and some physiological traits of chickpea (Cicerarietinum L.) under reduced irrigation. Legume Research, 38 (1) 2015: 66-71.

Ghafiyehsanj, E., K. Dilmaghani and H. H. Shoar, (2013).The effects of salicylic acid on some of biochemical characteristics of wheat (Triticumaestivum L.) under salinity stress. Ann. Biol. Res., 4: 242-248.

Gomez, K.A. and A.A. Gomez (1984) Statistical procedures for Agricultural Research. John Wiley and Sons, Inc., New York.

Hayat Q., S. Hayat, M. Irfan, A. Ahmad (2010). Effect of exogenous salicylic acid under changing environment: A review. Environ. Exp. Bot, 68: 14 25.

Khan, N. A.; S. Syeed; A. Masood; R. Nazar and N. Iqbal, (2010).Application of salicylic acid increases contents of nutrients and antioxidative metabolism in mungbean and alleviates adverse effects of salinity stress. Int. J. Plant Biol., 1: 1-8.

Lichtenthaler, H. K. 1987. Chlorophylls and carotenoids: pigments of photosynthetic biomembranes. Methods Enzymol, 148:350-382.

Lisar, S. Y. S., R. M otafakkerazad, M. M.Hossain, and I. M. M. Rahman, (2012). Water deficit stress in Plants: Causes, Effects and Responses. In: Rahman, I. M. M. \& Hasegawa, H. Water deficit stress, InTech, Croatia, p. 01-14.

Maswada H.F. and N. I. K. Abd El-Kader (2016) Redox halopriming: A promising strategy for inducing salt tolerance in bread wheat. J. Agro Crop Sci. 202, 37-50.

Michael, A. M. (1978).Irrigation theory and practice.Vikas publishing House PVT.Ltd. 
Miyake, C. (2010). Alternative electron flow (waterwater cycle and cyclic electron flow around PSI) in photosynthesis: molecular mechanisms and physiological function. Plant and Cell Physiol. 51: 1951-1963.

Noreen, S. and M. Ashraf. (2008). Alleviation of adverse effects of salt stress on sunflower (Helianthus annuus L.) by exogenous application of salicylic acid: Growth and photosynthesis. Pak. J. Bot. 40(4): 1657-1663.
Popova L., T. Pancheva, A. Uzunova (1997).Salicylic acid: properties, biosynthesis and physiological role. Bulg. J. Plant Physiol. 23:85-93.

MalikSamina, M. Ashraf1, M. Arshad and T. A. Malik (2015).Effect of ascorbic acid application on physiology of wheat under drought stress. Pak. J. Agri. Sci., Vol. 52(1), 209-217.

Shirazi S. M; Z.Yusop; N. H. Zardari and Z. Ismail (2014),Effect of Irrigation Regimes and Nitrogen Levels on the Growth and Yield of Wheat. Advances in Agriculture Volume (4), Article ID 250874, 6 pages

\section{تأثير الرش ببعض مضادات الاكسدة والاجهاد المائى عند مراحل نمو محددة على انتاجية محصول القمح

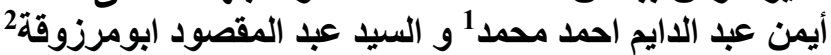

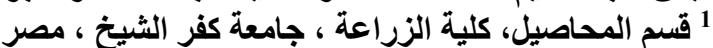

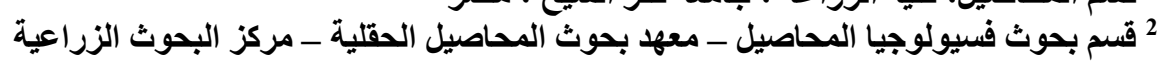

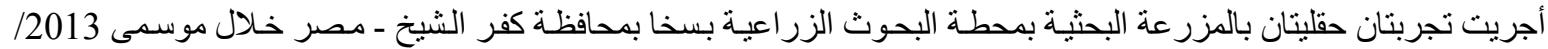

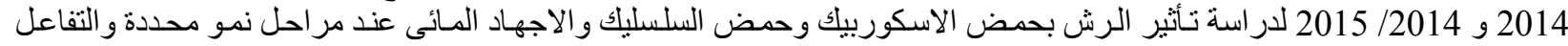

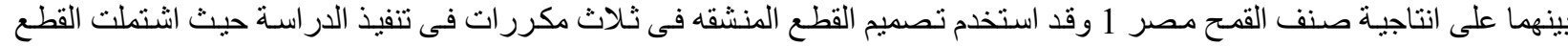

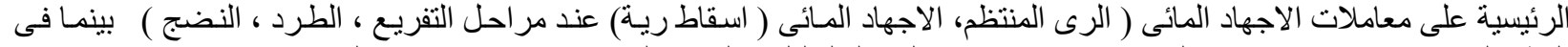

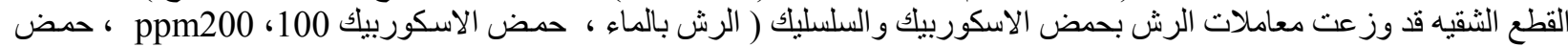

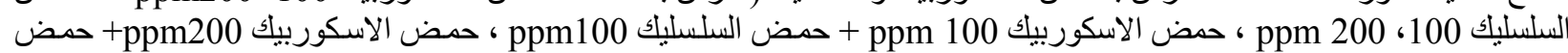

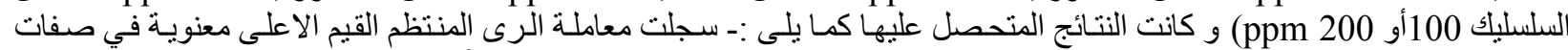

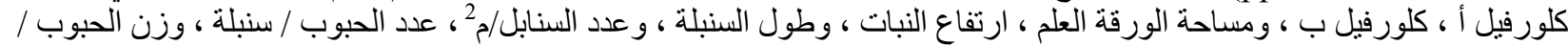

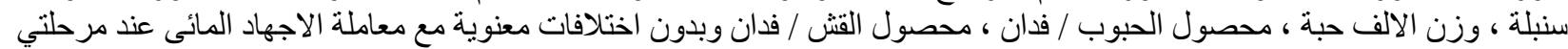

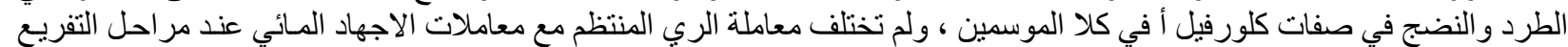

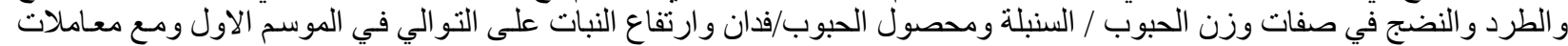

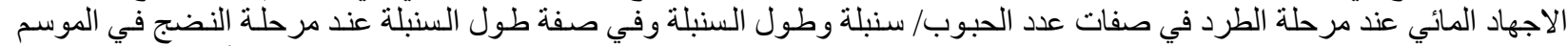

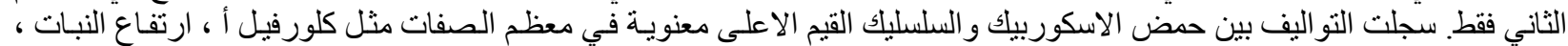

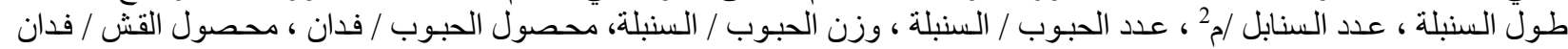

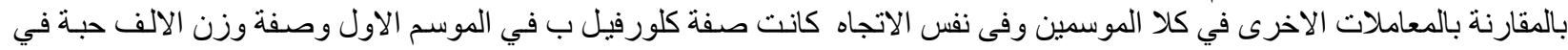

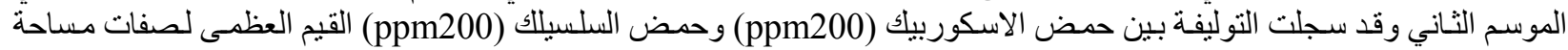

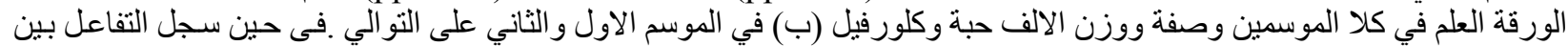

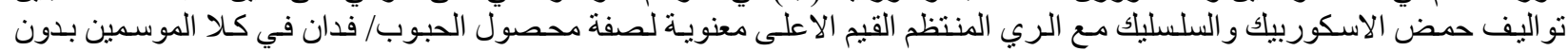

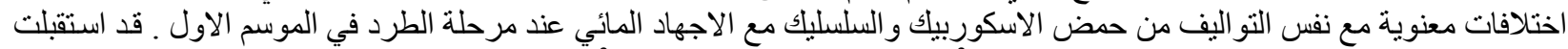

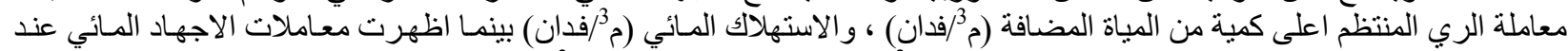

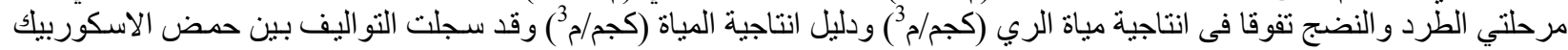

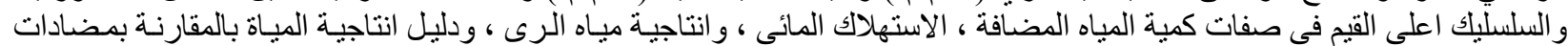

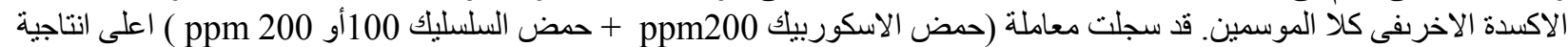

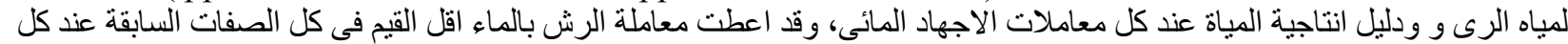

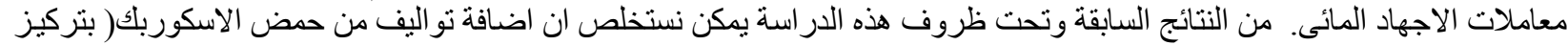

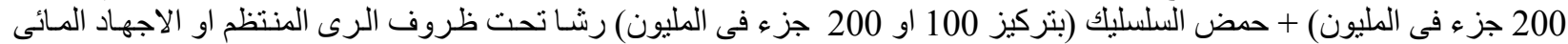

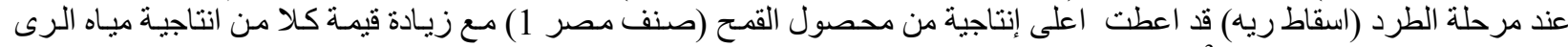

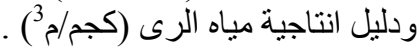

